\title{
Community and Campus COVID-19 Risk Uncertainty Under University Reopening Scenarios: Model-Based Analysis
}

James Benneyan, PhD; Christopher Gehrke; Iulian Ilies, PhD; Nicole Nehls, BSc

Healthcare Systems Engineering Institute, Northeastern University, Boston, MA, United States

Corresponding Author:

James Benneyan, $\mathrm{PhD}$

Healthcare Systems Engineering Institute

Northeastern University

360 Huntington Avenue $177 \mathrm{H}$

Boston, MA, 02115

United States

Phone: 16173736450

Email: j.benneyan@northeastern.edu

\section{Abstract}

Background: Significant uncertainty has existed about the safety of reopening college and university campuses before the COVID-19 pandemic is better controlled. Moreover, little is known about the effects that on-campus students may have on local higher-risk communities.

Objective: We aimed to estimate the range of potential community and campus COVID-19 exposures, infections, and mortality under various university reopening plans and uncertainties.

Methods: We developed campus-only, community-only, and campus $\times$ community epidemic differential equations and agent-based models, with inputs estimated via published and grey literature, expert opinion, and parameter search algorithms. Campus opening plans (spanning fully open, hybrid, and fully virtual approaches) were identified from websites and publications. Additional student and community exposures, infections, and mortality over 16-week semesters were estimated under each scenario, with $10 \%$ trimmed medians, standard deviations, and probability intervals computed to omit extreme outliers. Sensitivity analyses were conducted to inform potential effective interventions.

Results: Predicted 16-week campus and additional community exposures, infections, and mortality for the base case with no precautions (or negligible compliance) varied significantly from their medians (4- to 10-fold). Over 5\% of on-campus students were infected after a mean of 76 (SD 17) days, with the greatest increase (first inflection point) occurring on average on day 84 (SD 10.2 days) of the semester and with total additional community exposures, infections, and mortality ranging from 1-187, $13-820$, and $1-21$ per 10,000 residents, respectively. Reopening precautions reduced infections by $24 \%-26 \%$ and mortality by $36 \%-50 \%$ in both populations. Beyond campus and community reproductive numbers, sensitivity analysis indicated no dominant factors that interventions could primarily target to reduce the magnitude and variability in outcomes, suggesting the importance of comprehensive public health measures and surveillance.

Conclusions: Community and campus COVID-19 exposures, infections, and mortality resulting from reopening campuses are highly unpredictable regardless of precautions. Public health implications include the need for effective surveillance and flexible campus operations.

(JMIR Public Health Surveill 2021;7(4):e24292) doi: 10.2196/24292

\section{KEYWORDS}

COVID-19; university reopening; community impact; epidemic model; model; community; university; safety; strategy; risk; infectious disease

\section{Introduction}

The COVID-19 pandemic has had devastating human, financial, and logistical impacts worldwide, including over 125 million

infected and 2.75 million deaths as of March 2021 [1], radical changes to work and life routines, economic recession, and increased social inequities [2-5]. Among many other issues, significant uncertainties exist about the potential safety and consequences of reopening schools [6-9], heightened by 
resurgences in infections and mortality and campus $x$ community cross-exposure concerns $[9,10]$. Although much initial focus was on K-12 education [11-13], similar college and university reopening concerns exist $[9,10,14]$.

As COVID-19 spread uncontrollably during the spring of 2020 , nearly all K-12 and postsecondary schools suspended physical classes, with an estimated 50 million elementary students [13] and 19 million college students in the United States [15] shifting to online learning, homeschooling, and remote education, with experiences varied and often lacking [16-18]. Although a few universities decided early in summer 2020 to remain fully virtual for the following academic year, including the largest public university system in the United States [19,20], many schools decided to reopen under various structures. Since then, four events of import have occurred: several additional colleges and universities switched to full or partial online operations for the fall 2020 semester; COVID-19 has resurged in many regions; other schools have committed to opening as safely as possible; and debate has increased as to what best balances education, safety, and economic needs [21-26].

Examples of reopening approaches range from full on-campus operations with contact precautions; hybrid virtual/physical formats with some courses (or class meetings within given courses) taught virtually and others in-person; having only firstand/or second-year students on campus with all others virtual; student choice to take courses physically versus virtually; and (in the United States) accelerated semesters ending at the Thanksgiving holiday to reduce travel-based spread [27-29]. Efforts to limit on-campus exposures include reconfigured classrooms and dormitory spaces, precaution awareness campaigns, hotel room rentals to reduce living density, testing and tracing plans of varied rigor, isolation of returning students, dedicated living spaces for students with positive tests, and other strategies that attempt to reduce density and exposure rates [21,23,27,30-32].

Significant uncertainty, however, exists about the effectiveness of any of these plans $[21,23,31,33]$. The best current diagnostic tests have variable and poor clinical sensitivity [25,34] and turnaround delays, while incubation from the time of exposure to becoming symptomatic averages 3-5 days [35-37]. Furthermore, an estimated $30 \%-40 \%$ of positive individuals never exhibit symptoms [25,34,35], and on-campus compliance to distancing precautions generally is low $[25,30,38,39]$. Contact tracing, while helpful, may not work as well for COVID-19 given the above $[9,33]$ and may be further limited in the campus context as students interact with many-fold more individuals (many unknowingly or unknown by name).

These uncertainties have prompted some to question university reopening safety $[6,8,14,25,26,31,40]$, especially in urban university settings with significant geographically dispersed student populations [41]. Others have suggested COVID-19 might catalyze the reinvention of higher education [42-45], including criticisms of prioritizing economics, brand, and survival over safety $[22,43,44,46]$. The president of Paul Quinn College, by example, stated "Rushing to reopen our society and our schools is a mistake that will ultimately result in hundreds of thousands of citizens falling sick and worse. We should not let our own financial and reputational worries cloud our judgment about matters of life and death" [8]. In contrast, not reopening may have large economic and student development effects [47-49], although perhaps less of both effects compared to not reopening K-12 schools. Not reopening could also be untenable for colleges and universities that were already facing financial strains before COVID-19 emerged [48-50].

Although little empirical data exist on college reopening [40,51-56], experiences of preschool, summer camp, and K-12 programs have been varied $[57,58]$, with some outbreaks traced back to only a few index cases [21]. Social gatherings of college-age students during summer 2020 also have resulted in outbreaks [38,58,59], including events and activities individuals were advised against but participated in nonetheless [30,38]. Despite early uncertainty, increasing evidence suggests student-aged individuals can carry and transmit the SARS-CoV-2 virus $[35,58,60,61]$ and significant between-student spread occurs at college and high school levels $[35,58,61]$ (in contrast to younger K-5 students [35,47,61,62]). The impact of campus opening on spread to the surrounding community, with higher percentages of at-risk individuals, has been less reported on.

Given these combined uncertainties, we developed single and multiple population COVID-19 spread models to investigate the predictability of potential community and campus impacts under various reopening scenarios. The intent is to provide model-based analysis to better inform decision-making at a critical time in the COVID-19 pandemic. Although similar model analyses have extensively studied other infectious disease policies [63-66], there has been little investigation of university reopening and the impact on surrounding communities.

\section{Methods}

\section{Model Overview}

We developed and validated single and multiple population ordinary differential equations (ODE) and agent-based models of COVID-19 spread within and between defined groups of individuals. The general model logic (Multimedia Appendix 1) was a d a t e d f r m l a s i c susceptible-exposed-infected-recovered (SEIR) frameworks $[67,68]$ similar to those described elsewhere for many other infectious diseases [63-76]. The single population model describes spread dynamics within one defined population (eg, on-campus students or local community residents), whereas the multipopulation model additionally includes cross-exposure between two or more groups. Multiple change points were included for all parameters to allow for policy or behavior changes when fitting models to historical data.

State variables at time $t$ include the numbers of individuals in population $j$ that are free of and susceptible to COVID-19 $\left(S_{j}(t)\right)$, exposed to COVID-19 but not yet infectious themselves $\left(E_{j}(t)\right)$, COVID-19-positive and infectious to others $\left(I_{j}(t)\right)$, recovered and not susceptible to reinfection $\left(R_{j}(t)\right)$, and COVID-19-associated deceased $\left(D_{j}(t)\right)$. Exposed individuals are assumed to have a small chance $(p)$ of warding off an infection before becoming infectious. Recovered individuals 
are assumed not able to be reinfected within at least a 16-week (one semester) time frame [37,77]. Each state variable is updated numerically at each time increment (set here to 0.01 days) based on its previous value, values of other state variables at the previous time step, and the equations governing their interdependent relationships, with this process continuing iteratively for 16 weeks.

For example, the number of individuals in the susceptible population $\left(S_{j}(t)\right)$ is decremented by the number of newly exposed individuals $\left(S_{j}(t) \cdot\right.$ expo $\left._{j}\right)$ and increased by the number who previously were exposed but did not develop infections, $\left(E_{j}(t) \cdot \operatorname{expr}_{j}\right)$, where the daily exposure rate $\operatorname{expo}_{j}$, the average risk of transmission multiplied by the average number of contacts per day, is back-computed from the basic reproduction number $R_{0}$ (average number of new infections per infected individual) and recovery and mortality rates, and the recovery rate of noninfectious exposed individuals expr $_{j}$ is the inverse of the corresponding recovery time $t_{r e c, n o n j}$.

In turn, the number of exposed individuals is increased by $S_{j}(t)$ - expo $_{j}$ and decremented by the number who develop infections $\left(E_{j}(t) \cdot i n f e_{j}\right)$, where the daily infection rate infe $e_{j}$ is the ratio of the probability of becoming infected upon exposure $p_{j}$ over the average incubation time $t_{i n c j}$. Infected individuals either recover or die at rates of $i n f r_{j} \cdot I_{j}(t)$ and $\operatorname{mort}_{j} \cdot I_{j}(t)$, respectively, where the daily recovery and mortality rates are the inverse of the average recovery time $t_{r e c, \text { incj }}$ and the ratio of the overall COVID-19 case fatality rate for that population $\left(C F R_{j}\right)$ over the average time from infection until death $t_{i 2 d j}$, respectively.

The governing rate change dynamics for each state variable at each time step during numeric evaluation thus are the following:

$S_{j}(t)$ (susceptible; + not-infected/infectious (nor immune) after exposure - new exposures due to within-population and between-population contact with infectious individuals):

$$
\frac{d S_{j}(t)}{d t}=-\left(\begin{array}{c}
\left.\operatorname{expo}_{j} \cdot \frac{I_{j}(t)}{N_{j}(t)}+r i_{j} \sum_{i \neq j} \chi_{i, j} \cdot \operatorname{expo}_{i} \cdot \frac{I_{i}(t)}{N_{i}(t)}\right) \\
\cdot S_{j}(t)+\operatorname{expr}_{j} \cdot E_{j}(t)
\end{array}\right.
$$

$E_{j}(t)$ (exposed; + new exposures - past exposures now infected/infectious - past exposures now not infected/infectious [now susceptible]):

$$
\begin{gathered}
\frac{d E_{j}(t)}{d t}=\left(\operatorname{expoj}_{j} \cdot \frac{I_{j}(t)}{N_{j}(t)}+r i_{j} \sum_{i \neq j} \chi_{i, j} \cdot \operatorname{expo}_{i} \cdot \frac{I_{i}(t)}{N_{i}(t)}\right) \\
\cdot S_{j}(t)-(2)
\end{gathered}
$$

$I_{j}(t)$ (infectious; + past exposures now infected/infectious - past exposures now not infected - deaths):

$$
\frac{d I_{j}(t)}{d t}=\text { infe }_{j} \cdot E_{j}(t)-\left(\text { infr }_{j}+\text { mort }_{j}\right) \cdot I_{j}(t)
$$

$R_{j}(t)$ (recovered; + infected individuals who recover [with immunity]):

$$
\frac{d R_{j}(t)}{d t}=\inf r_{j} \cdot I_{j}(t)
$$

$D_{j}(t)$ (deceased; + COVID-19-related deaths):

$$
\frac{d D_{j}(t)}{d t}=\operatorname{mort}_{j} \cdot I_{j}(t)
$$

where

$$
\operatorname{expo}_{j}=R_{0, j} \cdot \frac{\text { infr }_{j}+\text { mort }}{j}
$$

(rate at which people transition from susceptible to exposed)

$$
\text { infe } e_{j}=\frac{p_{j}}{t_{\text {inc }}}
$$

(rate at which people transition from exposed to infected)

$$
\text { infr } r_{j}=\frac{1}{t_{\text {rec, }, \text { inf }_{j}}}
$$

(rate at which people transition from infected to recovered)

$$
\operatorname{expr} r_{j}=\frac{1-p_{j}}{t_{\text {rec,non }}}
$$

(rate at which people transition from exposed to recovered)

$$
\operatorname{mort}_{j}=\frac{C F R_{j}}{t_{i z d_{j}}}
$$

(rate at which people transition from infected to deceased) and

$$
N_{i}=S_{i}(t)+E_{i}(t)+I_{i}(t)+R_{i}(t)+D_{i}(t), \quad(\mathbf{1 1})
$$

(sum of all subpopulations in region $i$ at time $j$ )

where $\chi i, j=1$ if populations $i$ and $j$ interact and 0 otherwise and $p_{j}=$ the proportion of exposed individuals that transition to infected (versus recovering to susceptible). The multipopulation models allow for separate parameter values for each population, such as based on their demographics, with a cross-exposure parameter $\left(r i_{j}\right)$ defining the relative rate at which infectious individuals in one population expose susceptible individuals in the other (typically lower than within-population, assuming less interaction).

\section{Parameter Estimation and Model Calibration}

Model accuracy was validated using standard methods [65,78-82], cross-validation, and varied state and county empirical data (January to July 2020) exhibiting different epidemic patterns, magnitudes, and timings (Multimedia Appendix 2). Model results closely emulate historical data across multiple settings, with accuracy on par with or exceeding norms reported elsewhere [83-89] and with $\leq 1$ change points generally providing good fits, suggesting good prospective short-term prediction capability.

Model inputs (Table 1) used in the community and campus models were estimated using a combination of published and grey literature, expert opinion, and search-based optimization. For campus inputs with uncertainty, we used Monte Carlo simulations to create 1000 synthetic results across plausible ranges, using the shown most likely, maximum, and minimum values to generate asymmetric triangular distribution random variates. Since little data exist about on-campus spread [21], for exposure rates we used the shown ranges for the average number of infected students divided by the exposed-to-infectious percentage. 
For community populations, we further calibrated inputs via a particle swarm search algorithm to minimize root mean square error differences between historical and model-predicted infections and mortality, running each parameter search 1000 times. For model fits with change points, separate values for all inputs were optimized for each time segment, with state variables at the start of each new time segment set to their values at the end of the prior segment.

Table 1. Model parameters in the COVID-19 campus $\times$ community epidemic models, estimated values, literature sources, and ranges used for parameter search and sensitivity analysis. "Rank order" indicates the relative significance of each parameter on campus (community; additional community) outcomes (16-week totals); only statistically significant factors are shown $(\alpha=.05)$.

\begin{tabular}{|c|c|c|c|c|c|c|c|}
\hline \multirow[t]{2}{*}{ Parameter } & \multirow[t]{2}{*}{ Definition } & \multirow{2}{*}{$\begin{array}{l}\text { Lower } \\
\text { bound }\end{array}$} & \multirow{2}{*}{$\begin{array}{l}\text { Most } \\
\text { likely }\end{array}$} & \multirow{2}{*}{$\begin{array}{l}\text { Upper } \\
\text { bound }\end{array}$} & \multirow[t]{2}{*}{ Sources } & \multicolumn{2}{|l|}{ Rank } \\
\hline & & & & & & Infection & Mortality \\
\hline$R_{0,1}$ & $\begin{array}{l}\text { Average number of students who become infected } \\
\text { by infectious students }\end{array}$ & 0.66 & 1 & 3.4 & [90] & $2(6 ; 3)$ & $5(-\mathrm{a} ; 3)$ \\
\hline$R_{0,2}$ & $\begin{array}{l}\text { Average number of residents infected by infectious } \\
\text { residents }\end{array}$ & 0.66 & - & 3.4 & [90], parameter search & $5(2 ; 2)$ & $-(5 ; 4)$ \\
\hline$r i_{j}$ & Cross-exposure parameter (campus $\times$ community) & 0.005 & 0.008 & 0.02 & Estimated & $6(6 ; 5)$ & $-(-; 8)$ \\
\hline$\pi_{1}$ & $\begin{array}{l}\text { Proportion of student population initially infected } \\
\text { at semester start }\end{array}$ & 0.001 & .01 & .05 & [91-93] & $4(-; 6)$ & $6(-; 9)$ \\
\hline$\pi_{2}$ & $\begin{array}{l}\text { Proportion of community population initially infect- } \\
\text { ed at semester start }\end{array}$ & 0.0016 & .01 & .016 & [94] & $-(4 ; 4)$ & $-(7 ; 10)$ \\
\hline$p_{j}$ & Proportion of exposed people that become infected & 0.5 & 0.9 & 1 & Estimated & $-(7 ;-)$ & $3(3 ; 5)$ \\
\hline$t_{i n c_{j}}$ & Incubation duration (in days) & 2 & 4.5 & 14 & {$[95,96]$} & $3(3 ; 7)$ & $7(6 ; 7)$ \\
\hline$t_{r e c}$ & Recovery duration (in days) & 6 & 14 & 42 & [97-99] & $1(1 ; 1)$ & $2(1 ; 1)$ \\
\hline$C F R_{1}$ & Fatality rate for college population & 0.001 & 0.0092 & 0.016 & {$[97,100]$} & $-(-;-)$ & $1(-;-)$ \\
\hline $\mathrm{CFR}_{2}$ & Fatality rate for community population & 0.01 & 0.06 & 0.15 & {$[101,102]$} & $-(5 ;-)$ & $-(2 ; 2)$ \\
\hline$t_{i 2 d_{j}}$ & Number of days from infection until death & 14 & 35 & 56 & [99] & $-(8 ;-)$ & $4(4 ; 6)$ \\
\hline
\end{tabular}

${ }^{\mathrm{a}}$ Not available.

For initial disease prevalence in the local community and among arriving students, we also used expected values and probability intervals from a logistic growth curve fit to historical COVID-19 infection counts, estimating prevalence among arriving students at the start of the fall 2020 semester using a weighted average of prevalence predictions based on home locations. Resulting community and student prevalence ranges were validated against data reported in the media. Positive individuals at the start of the semester were assumed distributed between exposed but not yet infectious $(24.3 \%)$ and infectious $(75.7 \%)$ groups based on approximate relative durations that an average infected individual might spend in each state. All model inputs were based on published literature listed in Table 1 or aggregate state and county infection and mortality online data [103] and thus not subject to human subjects internal review board approval.

\section{Reopening Scenario Analysis}

Common university reopening scenarios were identified from literature and published surveys [7,19], generally belonging to one of several categories (see Table 2 for examples), which then were used to estimate plausible ranges for $R_{0}$ reductions. The most common approaches included primarily or fully in-person (35\%), primarily or fully online (32\%), and hybrid (19\%) [7]. As examples, the University of Washington reopening plan [104] exemplifies a conservative approach, with more than $90 \%$ of courses taught online, courses relying on direct interactions (eg, medical and health sciences) taught in person with safety precautions, the majority of student services and advising taking place remotely, and any staff who can work remotely doing so. In contrast, Purdue University illustrates an opposite approach [105], with classes mainly taught on campus with contact precautions until the Thanksgiving break, relying on students to manage their personal safety. 
Table 2. Representative examples of US university and college COVID-19 fall 2020 semester campus reopening plans.

\begin{tabular}{|c|c|c|c|}
\hline Intervention description & Examples & Source & $\begin{array}{l}\text { Estimated reduc- } \\
\text { tion in } R_{0}(\%)\end{array}$ \\
\hline $\begin{array}{l}\text { Remote coursework for classes over } 50 \text {, testing, contact tracing, health } \\
\text { surveillance in dorms }\end{array}$ & University of Washington & {$[104,106]$} & 36 \\
\hline $\begin{array}{l}\text { Remote option available, social distancing, shortened semester, flexible } \\
\text { start dates for international students }\end{array}$ & Rice University & [107] & 25 \\
\hline $\begin{array}{l}\text { Face masks, social distancing, limited classes, some coursework online, } \\
\text { fewer students living on campus, shorter semester }\end{array}$ & Stanford University & [108] & 33 \\
\hline $\begin{array}{l}\text { More online classes, masks, social distancing, testing, health surveillance, } \\
\text { sanitizing and washing stations }\end{array}$ & Ohio State University & {$[109,110]$} & 30 \\
\hline $\begin{array}{l}\text { Some classes online, expanded housing, social distancing, face masks, } \\
\text { staggered hours, increased cleaning, testing, tracing }\end{array}$ & Northeastern University & {$[32,111]$} & 49 \\
\hline $\begin{array}{l}\text { Most classes online except those for which in-person instruction is deemed } \\
\text { necessary }\end{array}$ & California State University & {$[112,113]$} & 12 \\
\hline $\begin{array}{l}\text { Students back on campus for a shortened fall semester as long as they } \\
\text { follow Connecticut reopening suggestions }\end{array}$ & Connecticut State institutions & {$[114,115]$} & 46 \\
\hline
\end{tabular}

As most reopening plans involve reducing either interpersonal contact or infection spread, we implemented these as multiplicative reductions in the reproduction number $R_{0}$, with effect sizes of individual actions estimated via literature estimates and expert opinion. Overall scenarios then were defined with estimated effects on $R_{0}$ spanning the base case of no change, small $25 \%$ cumulative reductions (eg, Rice University, Ohio State), moderate $50 \%$ reductions (eg, Northeastern University, Connecticut State), and $75 \%$ reductions as a best-case scenario for comparison, with each scenario coupled with initial student infection rates of $0.1 \%, 1 \%, 2 \%$, and $5 \%$ based on university reporting.

For each scenario, 1000 model replications were run for campus alone, community alone, and campus $\times$ community combined to estimate additional cross-exposure impacts of each population on the other. For the campus $\times$ community cases, each of the 1000 community parameterizations were randomly coupled with the 1000 random sets of campus inputs, with the two populations interacting via 1000 random values of the cross-exposure parameter, $r i$, sampled from the range shown in Table 1.

Given that the ratio of campus-to-community population sizes may affect cross-infection results and prevention policies, we assumed three general settings: (1) an urban campus of 10,000 students with 100,000 residents living in the immediately surrounding residential areas or neighborhoods (in which off-campus students tend to reside); (2) a student body of the same size $(10,000)$, but with fewer $(40,000)$ residents living close to the campus; and (3) a smaller number of 2000 students with 40,000 residents living near campus. The first scenario might represent a large university in a major city, whereas the second might represent a large rural university, and the third a smaller undergraduate college in a nonurban setting, although these student-to-community populations (1:10, 1:4, and 1:20) can be extrapolated to other settings with similar ratios.
Monthly and total counts of COVID-19 exposures, infections, and deaths for each population were tabulated and plotted longitudinally. First inflection points (dates of steepest increases) for each outcome, scenario, and population were identified numerically, since in diffusion theory interventions after these points tend to be less effective. To estimate cross-exposure effects, pairwise differences were computed between each of the 1000 campus results and their campus $\times$ community counterparts, and similarly between each of the 1000 community results and their campus $\times$ community counterparts. For all model results, medians, standard deviations, and $95 \%$ probability intervals were computed, with $10 \%$ trimming to reduce any extreme outlier replicate effects.

Sensitivity analyses were conducted to identify model inputs to which the mean and variance of results are most sensitive via central composite factorial experimental designs [116] as this could inform policy-making, interventions, and target setting. Results were analyzed using general linear models including linear and pairwise interaction terms for each outcome (replication means and variances of total and additional campus and community infections and deaths), with resulting effect coefficients normalized to their corresponding ranges and ranked according to statistical significance.

\section{Results}

\section{On-Campus/Student Impact}

Within any given assumptions for COVID-19 prevalence among arriving students and semester initialization precautions, the predicted number of students per 10,000 who might be exposed, be infectious, and die over a 16-week semester could vary by up to 10 -fold (Figure 1). By semester end, under the base case (2\% arrival prevalence, little returning precautions and/or effectiveness) predicted student outcomes range from 471-9458 infections (median 2286, SD 2627) and 0-123 deaths (median 9, SD 14). 
Figure 1. Predicted number of college students per 10,000 who are currently exposed to COVID-19, have been infected to date, and have died to date over a 16-week fall 2020 semester (urban university example). Top row: base case scenario assuming no semester initiation precautions and disease prevalence of $2 \%$ among arriving students (equal to national and regional averages). Shaded middle rows (most likely cases): realistic (1\%) and idealistic $(0.1 \%)$ initial prevalence scenarios assuming good or great screening-on-arrival precautions, adherence, and effectiveness. Bottom row: worst case scenario (5\% prevalence) assuming little-to-no arrival precautions, compliance, and effectiveness.

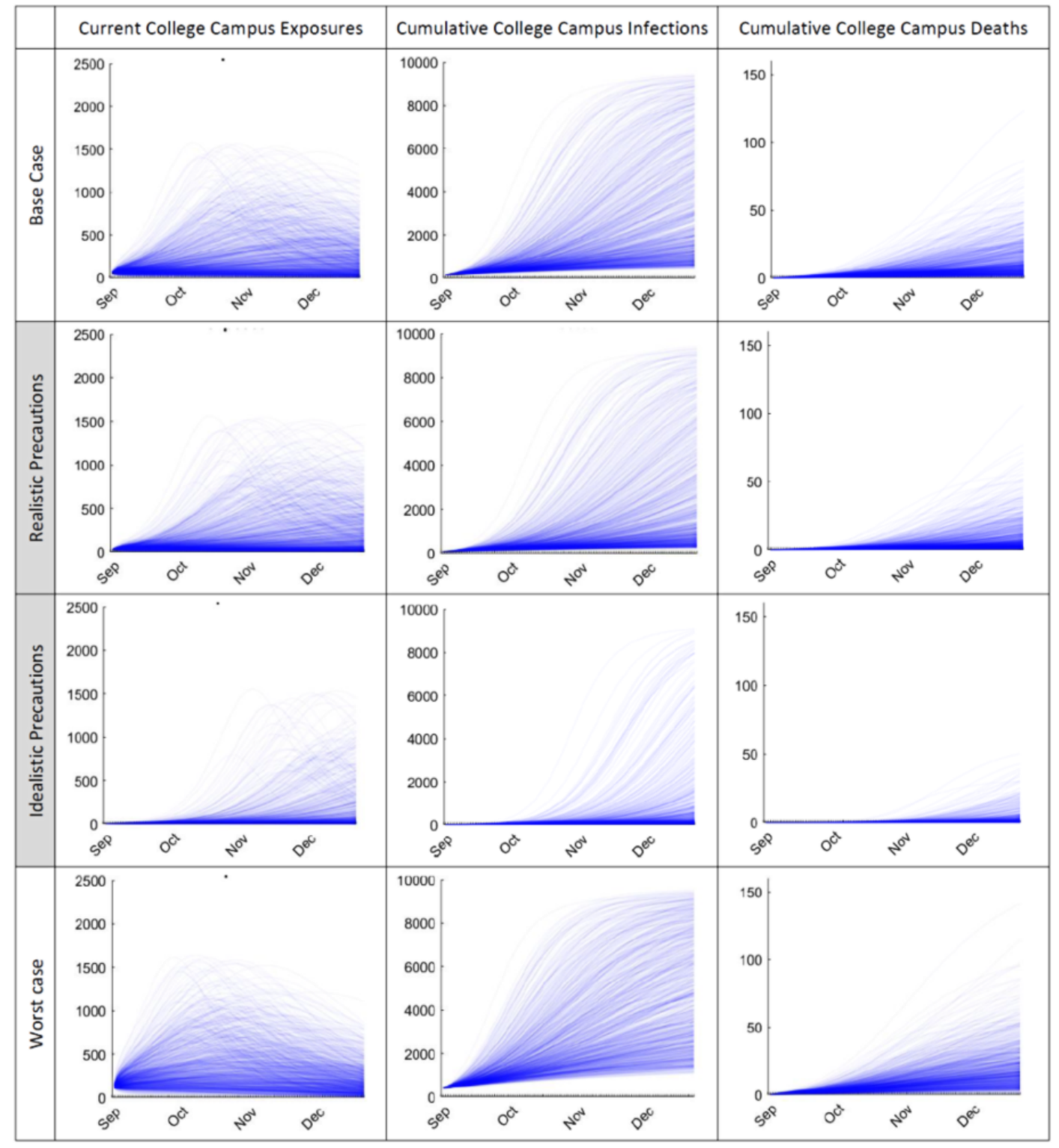

The more realistic case (1\% arrival prevalence) reduces these consequences to a median of 1332 (SD 2552) infections and 5 (SD 12) deaths, with the steepest increases in exposures and infections typically occurring at midsemester onward (with important implications on geographic spread as students return to their home communities). Although less likely, idealistic $(0.1 \%)$ and worst-case $(5 \%)$ initial prevalence scenarios were also considered for comparison, given that epidemic prevalence might change in future semesters. The first would result in a median of 158 (SD 1760) infections and 1 death (SD 6 deaths) by semester end and the latter in 3996 (SD 2485) infections and 16 (SD 17) deaths.

Note that the left-hand plots in Figure 1 depict the current number of exposed people on any given day (with each exposure spanning several days) in order to give an indication of the changing amount of contract tracing and isolation required, as well as the changing population risk, whereas the other plots depict the cumulative number of infections and deaths to date in order to summarize the total public health impact. Under the base case scenario, the number of active student exposures at any given time (eg, for contact tracing and isolation) ranged from 3-1576 per 10,000 individuals (eg, as high as $15 \%$ of a student population), with significant implications on resource planning and viability (Table 3 ). Under the two most likely scenarios, by midsemester the total number of infections might be as high (mean plus one standard deviation) as 810 per 10,000 students (with 4 deaths) or as low (mean minus one standard deviation) as 782 per 10,000 students (with 0 deaths). 
Table 3. Predicted median number of monthly COVID-19 exposures, infections, and deaths per 10,000 students during fall 2020 (northeast US urban university example). Values in parentheses indicate $95 \%$ probability ranges.

\begin{tabular}{|c|c|c|c|c|c|c|c|c|c|c|c|c|}
\hline \multirow[t]{2}{*}{ Scenario } & \multicolumn{3}{|l|}{ September } & \multicolumn{3}{|l|}{ October } & \multicolumn{3}{|l|}{ November } & \multicolumn{3}{|l|}{ December } \\
\hline & Exposure & Infection & $\begin{array}{l}\text { Mortali- } \\
\text { ty }\end{array}$ & Exposure & Infection & $\begin{array}{l}\text { Mortali- } \\
\text { ty }\end{array}$ & Exposure & Infection & $\begin{array}{l}\text { Mortali- } \\
\text { ty }\end{array}$ & Exposure & Infection & $\begin{array}{l}\text { Mortali- } \\
\text { ty }\end{array}$ \\
\hline Base case & $\begin{array}{l}474(175- \\
1840)\end{array}$ & $\begin{array}{l}318(146- \\
1181)\end{array}$ & $1(0-3)$ & $\begin{array}{l}708(160- \\
4731)\end{array}$ & $\begin{array}{l}510(131- \\
3561)\end{array}$ & $2(1-11)$ & $\begin{array}{l}925(124- \\
3532)\end{array}$ & $\begin{array}{l}685(105- \\
2946)\end{array}$ & $3(0-16)$ & $\begin{array}{l}638(74- \\
1934)\end{array}$ & $\begin{array}{l}522(63- \\
1576)\end{array}$ & $2(0-12)$ \\
\hline $\begin{array}{l}\text { Realistic } \\
\text { arrival } \\
\text { precau- } \\
\text { tions }\end{array}$ & $\begin{array}{l}245(89- \\
1011)\end{array}$ & $\begin{array}{l}163(74- \\
639)\end{array}$ & $1(0-2)$ & $\begin{array}{l}392(84- \\
3723)\end{array}$ & $\begin{array}{l}278(68- \\
2777)\end{array}$ & $1(0-8)$ & $\begin{array}{l}554(67- \\
4024)\end{array}$ & $\begin{array}{l}411(56- \\
3304)\end{array}$ & $2(0-14)$ & $\begin{array}{l}504(41- \\
2279)\end{array}$ & $\begin{array}{l}389(36- \\
1874)\end{array}$ & $2(0-12)$ \\
\hline $\begin{array}{l}\text { Idealistic } \\
\text { arrival } \\
\text { precau- } \\
\text { tions }\end{array}$ & $\begin{array}{l}26(9- \\
113)\end{array}$ & $17(7-69)$ & $0(0-0)$ & $\begin{array}{l}44(9- \\
769)\end{array}$ & $\begin{array}{l}30(7- \\
476)\end{array}$ & $0(0-1)$ & $\begin{array}{l}70(7- \\
3072)\end{array}$ & $\begin{array}{l}49(6- \\
2133)\end{array}$ & $0(0-5)$ & $\begin{array}{l}76(5- \\
2997)\end{array}$ & $\begin{array}{l}56(4- \\
2366)\end{array}$ & $0(0-8)$ \\
\hline $\begin{array}{l}\text { Worst } \\
\text { case }\end{array}$ & $\begin{array}{l}1084 \\
(415- \\
3613)\end{array}$ & $\begin{array}{l}744(353- \\
2398)\end{array}$ & $3(1-8)$ & $\begin{array}{l}1377 \\
(354- \\
4623)\end{array}$ & $\begin{array}{l}1026 \\
(301- \\
3895)\end{array}$ & $5(1-17)$ & $\begin{array}{l}1225 \\
(248- \\
2840)\end{array}$ & $\begin{array}{l}994(221- \\
2380)\end{array}$ & $5(1-19)$ & $\begin{array}{l}624(122- \\
1406)\end{array}$ & $\begin{array}{l}537(114- \\
1214)\end{array}$ & $3(1-12)$ \\
\hline
\end{tabular}

Similar results occur assuming the various semester precautions summarized in Table 2, corresponding to plausible reductions in $R_{0}$ of $25 \%-50 \%$ (Figure 2). In general, current strategies to reduce exposure during a semester appear effective, although under most scenarios a concerning number of students still can become infected or die. Even in the very optimistic case of a $75 \% R_{0}$ reduction, included for comparison as a hypothetical "best case" scenario, 95-132 infections (median 107) and 1 death per 10,000 students may occur by midsemester, increasing to 97-139 infections and 0-3 deaths by semester end. 
Figure 2. Relative effectiveness of reopening and precaution strategies on reducing college campus student COVID-19 exposures at any given date, total infections to date, and total mortality to date per 10,000 students (fall 2020 semester, assuming $1 \%$ of students are infected or exposed at the start of the semester, urban university example). Top row: base case from Figure 1 for comparison; shaded middle rows (most likely cases): realistic precaution effectiveness and compliance cases; bottom row: idealistic precaution effectiveness and compliance. Reduced exposure risk refers to reducing R0.

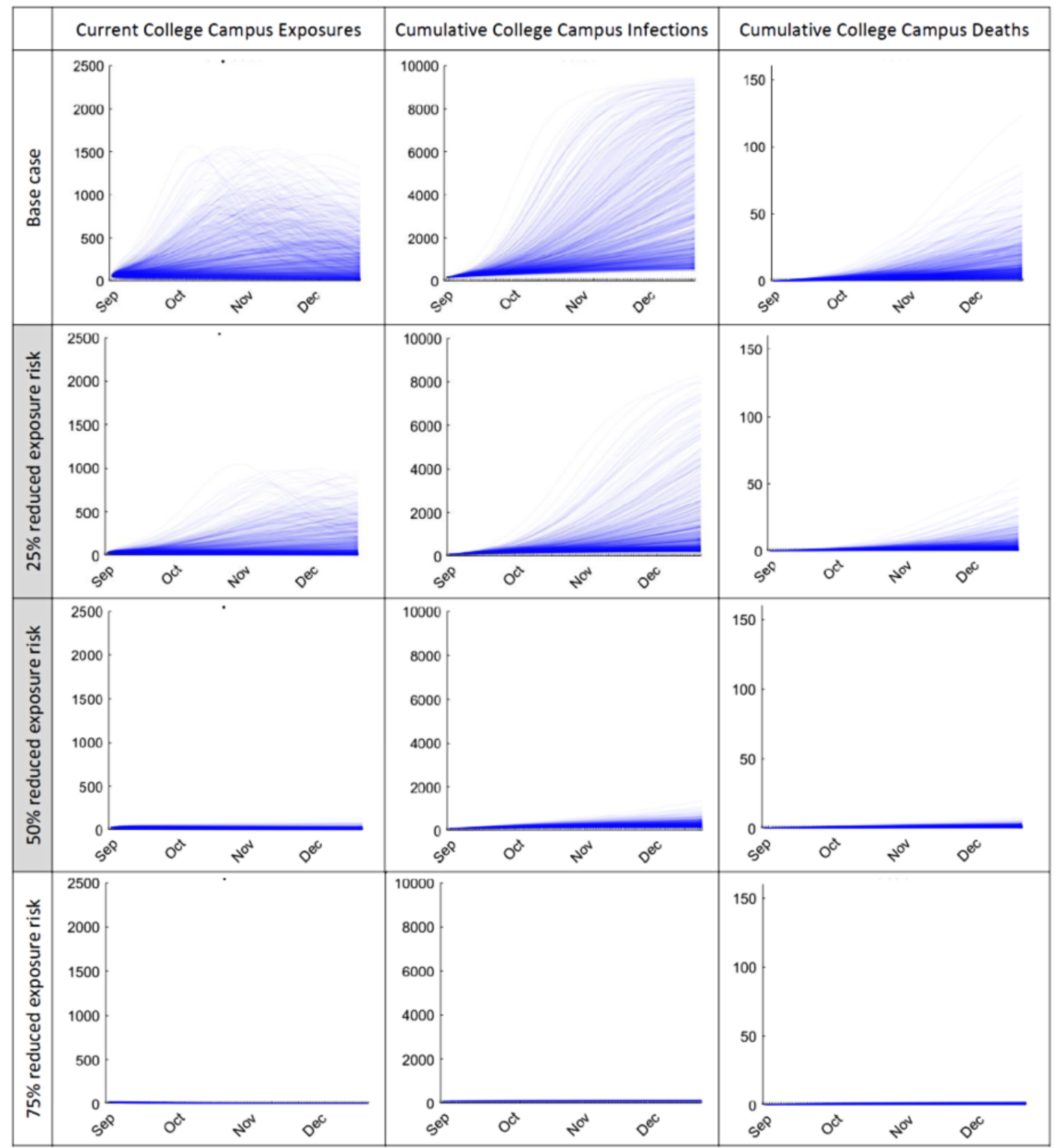

\section{Community Resident Impact}

Figure 3 summarizes additional community (blue lines) and campus (red lines) impacts of reopening due to campus $x$ community cross-exposure, assuming the same scenarios described above; for comparison, the top row shows the baseline number of community exposures, infections, and mortality without reopening. Local community impacts (Table 4) of opening with little-to-no semester operation precautions and/or adherence might range from 1-9768 additional community infections (median 158, SD 1131) and 0-491 additional community deaths (median 6, SD 53).

The two more realistic scenarios result in a total of (for $25 \%$ exposure reduction) 1-5577 additional community infections (median 56, SD 516) and 0-272 additional community deaths (median 3, SD 24), and (for 50\% exposure reduction) 0-464 additional community infections (median 14, SD 45) and 0-23 additional community deaths (median 1, SD 2 ). For comparison, the hypothetical best-case scenario with $75 \%$ exposure reduction results in 0-33 additional community infections (median 2, SD 4 ) and 0-2 additional community deaths (median 0, SD 0.2). 
Figure 3. Additional (red) community and (blue) college campus COVID-19 exposures, infections, and mortality due to community $\times$ campus cross-exposure (fall 2020 semester, prevalence among arriving students varied between $0.1 \%-2 \%$, urban university example). No interaction: total outcomes assuming no interaction between school and community. Base case: additional outcomes due to campus reopening assuming little-to-no campus semester operation precautions, compliance, or effectiveness. Shaded rows (most likely cases): additional outcomes assuming likely and ideal cases for campus operation precautions, adherence, and effectiveness. Bottom row: additional outcomes under a best case scenario assuming very high campus semester operation precautions, compliance, and effectiveness.

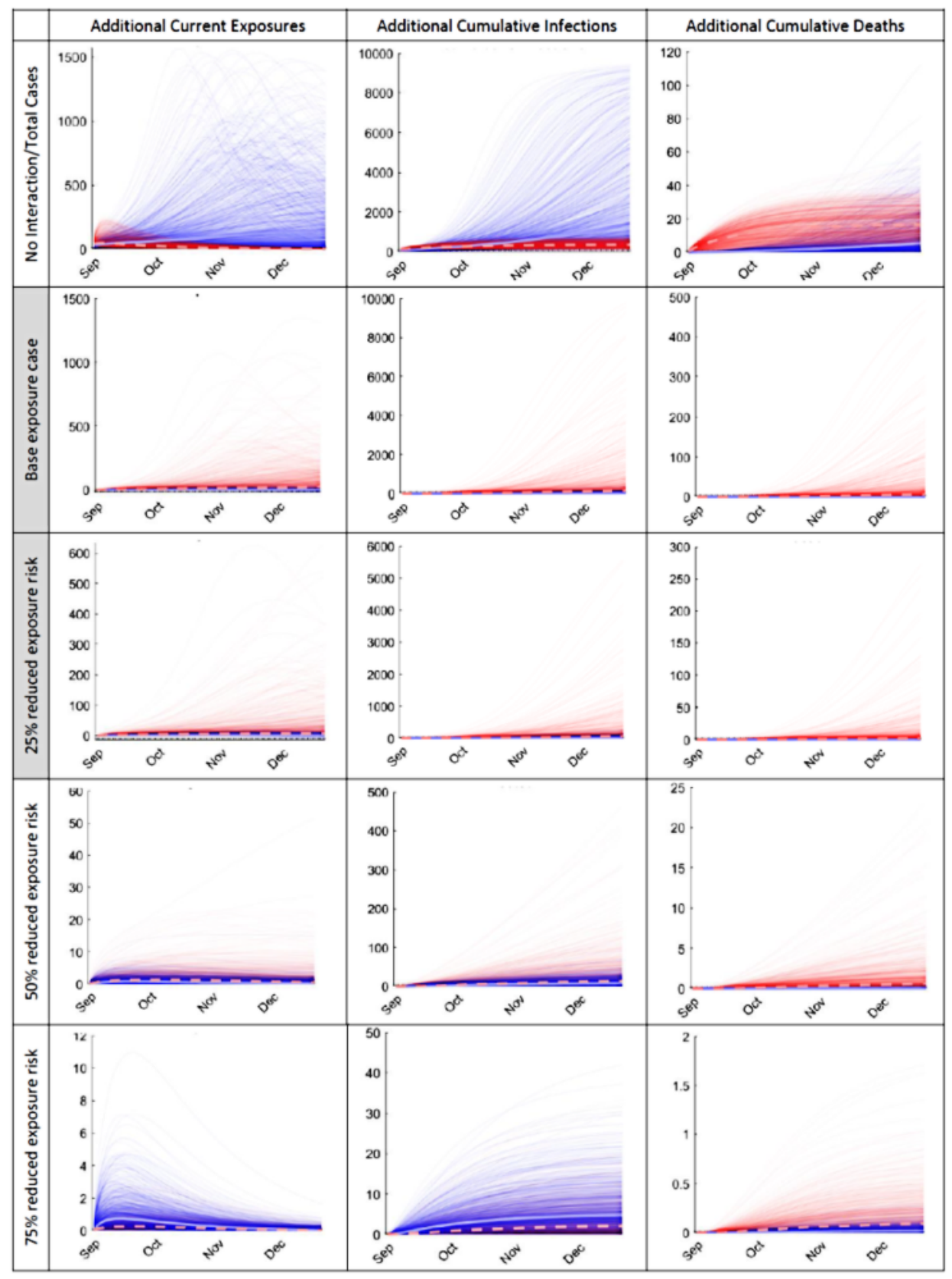


Table 4. Predicted monthly total campus and community COVID-19 outcomes (per 10,000) during the fall 2020 semester. (A) Total community resident outcomes assuming no university interaction, (B) additional community resident outcomes due to campus $\times$ community spread, and (C) additional university student outcomes (urban university example). Tabulated values are medians across 1000 replicates; values in parentheses indicate $95 \%$ probability ranges.

\begin{tabular}{|c|c|c|c|c|c|c|c|c|c|c|c|c|}
\hline \multirow{2}{*}{$\begin{array}{l}\text { Scenario (expo- } \\
\text { sure risk) }\end{array}$} & \multicolumn{3}{|c|}{ September } & \multicolumn{3}{|c|}{ October } & \multicolumn{3}{|c|}{ November } & \multicolumn{3}{|c|}{ December } \\
\hline & $\begin{array}{l}\text { Expo- } \\
\text { sure }\end{array}$ & Infection & $\begin{array}{l}\text { Mortali- } \\
\text { ty }\end{array}$ & $\begin{array}{l}\text { Expo- } \\
\text { sure }\end{array}$ & Infection & $\begin{array}{l}\text { Mortali- } \\
\text { ty }\end{array}$ & $\begin{array}{l}\text { Expo- } \\
\text { sure }\end{array}$ & Infection & $\begin{array}{l}\text { Mortali- } \\
\text { ty }\end{array}$ & $\begin{array}{l}\text { Expo- } \\
\text { sure }\end{array}$ & Infection & $\begin{array}{l}\text { Mortali- } \\
\text { ty }\end{array}$ \\
\hline
\end{tabular}

(A) Community outcomes assuming no university interaction (per 10,000)
Monthly to-
$11(0$
158
455)
$181(122-7(4-28) \quad 1(0-8)$
$182(122-7(4-29)$
tals
64) 362)
486)
495)

(B) Additional community outcomes due to campus reopening (total)

$\begin{array}{lcccccccccccc}\text { Base case } & 6(1-24) & 9(2-26) & 0(0-1) & 11(1- & 32(6- & 1(0-4) & 13(1- & 78(10- & 3(0-10) & 14(1- & 124(14- & 5(1-19) \\ & & & & 69) & 126) & & 148) & 415) & & 180) & 755) \\ \begin{array}{l}25 \% \text { reduced } \\ \text { exposure }\end{array} & 3(1-14) & 6(2-17) & 0(0-1) & 4(0-23) & 17(4-56) & 1(0-2) & 6(0-42) & 32(5- & 1(0-5) & 6(0- & 48(7- & 2(0-7) \\ \begin{array}{l}50 \% \text { reduced } \\ \text { exposure }\end{array} & 1(0-4) & 3(1-7) & 0(0-0) & 1(0-3) & 6(1-16) & 0(0-1) & 1(0-3) & 9(2-23) & 0(0-1) & 0(0-2) & 10(2-29) & 1(0-1) \\ \begin{array}{l}75 \% \text { reduced } \\ \text { exposure }\end{array} & 0(0-1) & 1(0-2) & 0(0-0) & 0(0-0) & 1(0-3) & 0(0-0) & 0(0-0) & 1(0-4) & 0(0-0) & 0(0-0) & 1(0-4) & 0(0-0)\end{array}$

(C) Additional university outcomes due to campus reopening (total)

$\begin{array}{llllllllllllll}\text { Base case } & 0(0-5) & 1(0-10) & 0(0-0) & 1(0-8) & 3(0-30) & 0(0-0) & 0(0-10) & 5(0-56) & 0(0-0) & 0(0-8) & 6(0-76) & 0(0-0) \\ \begin{array}{l}25 \% \text { reduced } \\ \text { exposure }\end{array} & 0(0-4) & 1(0-9) & 0(0-0) & 0(0-5) & 2(0-22) & 0(0-0) & 1(0-5) & 3(0-36) & 0(0-0) & 0(0-5) & 4(0-46) & 0(0-0) \\ \begin{array}{l}50 \% \text { reduced } \\ \text { exposure }\end{array} & 0(0-3) & 1(0-7) & 0(0-0) & 0(0-2) & 1(0-14) & 0(0-0) & 0(0-1) & 1(0-19) & 0(0-0) & 0(0-1) & 2(0-21) & 0(0-0) \\ \begin{array}{l}75 \% \text { reduced } \\ \text { exposure }\end{array} & 0(0-2) & 1(0-6) & 0(0-0) & 0(0-1) & 1(0-11) & 0(0-0) & 0(0-0) & 1(0-13) & 0(0-0) & 0(0-0) & 1(0-13) & 0(0-0)\end{array}$

The corresponding impact of the community on student outcomes is smaller, ranging from 0-390 additional student infections (median 21, SD 38) and 0-2 additional student deaths (median 0, SD 0.2) for the base case to 0-42 additional student infections (median 5, SD 6) and 0 additional student deaths (median 0, SD 0.04) for the idealistic case $(75 \%$ exposure reduction). The two more likely cases result in (for $25 \%$ exposure reduction) 0-279 additional student infections (median 17, SD 30) and 0-1 additional student deaths (median 0, SD 0.1 ), and (for $50 \%$ exposure reduction) $0-115$ additional student infections (median 8, SD 12) and 0-1 additional student deaths (median 0, SD 0.06).

To estimate the impact of school size and location, Figure 4 compares results under other student-to-community population sizes, assuming the same arrival prevalence and campus operation precautions, compliance, and effectiveness scenarios. While intuitive differences exist in raw totals, results are similar and scale-invariant after adjusting for population size. For example, multiplying results for the second case of 40,000 residents by 2.5 yields similar curves to those for the first case of 100,000 residents. This suggests that the above results may generalize to other settings and that between-location differences in epidemic patterns (and therefore in public policies to limit spread) likely arise from variations in campus $\times$ community interaction, rather than in population ratios. 
Figure 4. Impact of school-to-community population sizes on predicted additional community resident (red) and student (blue) COVID-19 current exposures, total infections, and total deaths per 10,000 individuals during the fall 2020 semester, assuming $1 \%$ prevalence among returning students and effective campus operations precautions (50\% R0 reduction). Urban large university: 10,000 students, 100,000 community residents; nonurban large university: 10,000 students, 40,000 community residents; small college nonurban: 2000 students, 40,000 community residents.

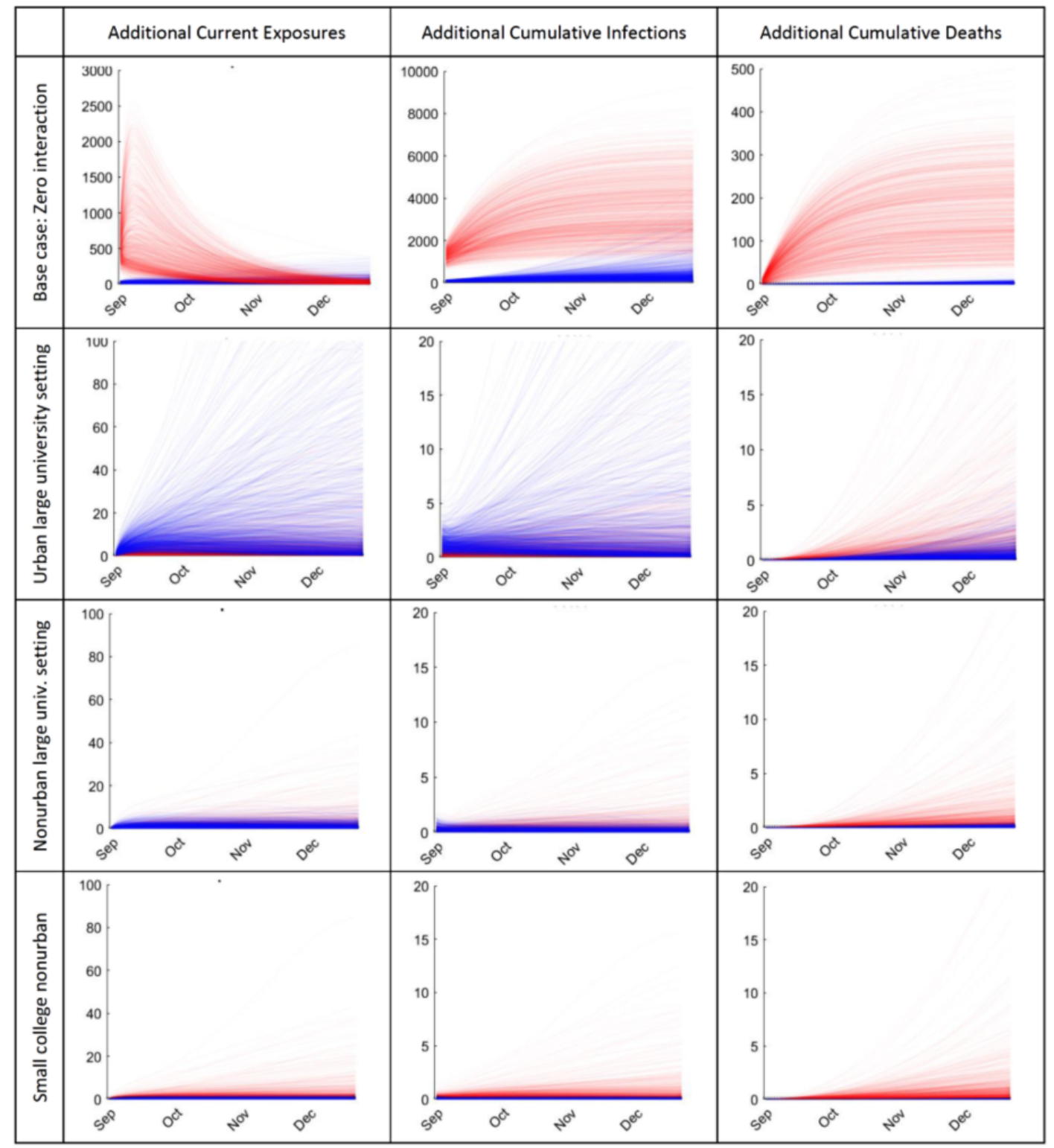

Finally, factorial sensitivity analysis produced the relative parameter rankings shown in the two rightmost columns of Table 2, which follow intuition and serve as further model validation. The most statistically significant factors (main effects) affecting the expected (Multimedia Appendix 3) and variation (Multimedia Appendix 4) in total campus infections were recovery time, $R_{0 \text {, campus }}$, incubation time, initial prevalence among arriving students, and $R_{0, \text { community }}$. Similarly, for total community infections, the most important factors were recovery time, $R_{0, \text { community }}$ incubation time, initial prevalence among community residents, and community case fatality rate. Numerous interaction terms were also significant in both cases, as would be expected in such a model.

For additional community infections, no dominant factors that affect either magnitude or variability of outcomes were evident beyond the basic reproduction numbers of each population $\left(R_{0, \text { campus }}, R_{0, \text { community }}\right)$ and the campus $\times$ community cross-exposure rate $r i$. The large number of other statistically significant main effects and interaction terms also underscore the multidimensional challenge of predictably limiting community impact and by extension the importance of effective surveillance and mitigation.

\section{Discussion}

\section{Principal Findings}

The COVID-19 pandemic continues to be a significant public health crisis, with infections and mortality in many regions meeting or exceeding those in early 2020 before physical distancing and closures were implemented. With many colleges and universities reopening, model-based analyses can help inform these important decisions as well as the degree of uncertainty in the resulting outcomes. Three important results of the present analysis are the following: (1) infections and mortality from campus reopening are highly variable and nearly 
impossible to predict with any certainty, (2) reopening campuses can significantly impact local communities even under best-case scenarios, and (3), while few exist, prevention and public health measures that target campus $\times$ community exposure could be effective.

While conditions may exist under which reopening is relatively safe to the local community, at present these appear in the significant minority. Our results also agree in general with emerging empirical data from the fall 2020 semester, including reports that COVID-19 deaths in US communities with open colleges roughly doubled from August to December 2020, compared with a smaller $58 \%$ average increase in communities without colleges. Genetic sequencing results further suggest that many deaths in college towns were of older people who had contact with infected students [117].

Several important public health implications of our results exist. First, decisions about whether to open in future academic terms or epidemics should be informed by updated model inputs, projections of local conditions, and campus $\times$ community public health measures. Second, since any trajectory within the produced intervals could occur, reopening decisions should consider these ranges rather than averages alone. Third, given the wide uncertainties in results from reopening, criteria should be established for rapidly detecting when to tighten precautions. Fourth, contact tracing and isolation capabilities should be ensured to be sufficient to respond to the range of model results.

Like any model-based analysis, results herein have some limitations and simplifications. A common barrier in such models is data availability for input estimation and results validation (hence our search-based approach). The deterministic ODE modeling framework ignores inherent variability and population heterogeneity [118], motivating our use of Monte Carlo analysis, parameter search replicates, and randomly sampled scenarios. Standard model simplifications include limiting the number of populations (eg, one overall homogenous community population), limiting spread to just SARS-CoV-2 (eg, ignoring seasonal influenza, substance abuse [75,76], and co-epidemic impacts), and not time-varying precaution compliance as concerns and vigilance relax or heighten over time. Some scenarios were also included for potential insights rather than being feasible in practice (eg, $75 \%$ reduction in $R_{0}$, near $100 \%$ precaution compliance).

Further work could expand on these results, including addressing some of the above simplifications, rerunning analyses for future semesters using more recent data for model calibration, and considering more heterogeneity in community and student populations. Future work could also seek to determine combined conditions (reduced prevalence, vaccine effectiveness, improved precaution methods, etc) under which outcomes are both safer and more certain. Public health reopening and precaution decisions at citywide or statewide levels also might be examined, such as alternating on-campus semesters or limiting combined student densities, to manage net community risks.

\section{Conclusion}

Controlling the COVID-19 pandemic is extremely critical. Mathematical models can offer valuable insights to inform important public health and policy decisions, including potential community and campus impacts from university reopening. The analysis summarized herein suggests that outcomes over a 16-week semester can be highly unpredictable under any set of assumptions or precautions, with three important implications: (1) community impacts from campus reopening are highly difficult to predict in advance, (2) on- and off-campus surveillance and response methods therefore are critical, and (3) additional precautions to reduce impacts of open campuses on local communities appear warranted.

\section{Acknowledgments}

This research was supported in part by the National Science Foundation (CMMI-1742521) and National Institute of Drug Abuse (R21DA046776-01). The content is solely the responsibility of the authors and does not represent official views of either funder. The authors thank Basma Bargal for help with references.

\section{Conflicts of Interest}

None declared.

\section{Multimedia Appendix 1}

General logic of campus $\times$ community two-population COVID-19 disease spread model. Susceptible: individuals not currently infected but who can become infected; exposed: individuals who are exposed and potentially infected but not yet infectious to others; infected: individuals who are infected and can infect others; recovered: individuals who were infected, survived, and cannot become reinfected nor infect others within the study time frame; dead: individuals who were infected and died from COVID-19 or complications.

[PNG File, 92 KB-Multimedia Appendix 1]

\section{Multimedia Appendix 2}

Examples of COVID-19 model accuracy (2020): (A) US state (shown: Massachusetts, California, and Florida) and (B) US county (shown: Dougherty County, GA; Eagle County, CO; and Suffolk County, MA). Normalized root mean square errors, summarized in figure legends, show decent model accuracy results across multiple settings.

[PNG File, 212 KB-Multimedia Appendix 2] 


\section{Multimedia Appendix 3}

Impact expectation.

[DOCX File, 35 KB-Multimedia Appendix 3]

\section{Multimedia Appendix 4}

Impact predictability.

[DOCX File, 35 KB-Multimedia Appendix 4]

\section{References}

1. WHO Coronavirus Disease (COVID-19) Dashboard. World Health Organization. 2020. URL: https://covid19.who.int/ [accessed 2021-03-22]

2. Bonaccorsi G, Pierri F, Cinelli M, Flori A, Galeazzi A, Porcelli F, et al. Economic and social consequences of human mobility restrictions under COVID-19. Proc Natl Acad Sci U S A 2020 Jul 07;117(27):15530-15535 [FREE Full text] [doi: 10.1073/pnas.2007658117] [Medline: 32554604]

3. Pirtle WNL. Racial Capitalism: A Fundamental Cause of Novel Coronavirus (COVID-19) Pandemic Inequities in the United States. Health Educ Behav 2020 Aug;47(4):504-508 [FREE Full text] [doi: 10.1177/1090198120922942] [Medline: 32338071]

4. Di Renzo L, Gualtieri P, Pivari F, Soldati L, Attinà A, Cinelli G, et al. Eating habits and lifestyle changes during COVID-19 lockdown: an Italian survey. J Transl Med 2020 Jun 08;18(1):229 [FREE Full text] [doi: 10.1186/s12967-020-02399-5] [Medline: 32513197]

5. Baker SR, Bloom N, Davis SJ, Terry SJ. Covid-induced economic uncertainty. National Bureau of Economic Research. 2020. URL: http://www.nber.org/papers/w26983 [accessed 2021-03-25]

6. Sorrell M. Colleges are deluding themselves. The Atlantic. 2020 May 15. URL: https://www.theatlantic.com/ideas/archive/ 2020/05/colleges-that-reopen-are-making-a-big-mistake/611485/ [accessed 2021-03-22]

7. Cai W, Ivory D, Smith M, Lemonides A, Higgins L. More than 6,600 coronavirus cases have been linked to US colleges. The New York Times. 2020 Jul 29. URL: https://www.nytimes.com/interactive/2020/07/28/us/covid-19-colleges-universities. $\underline{\mathrm{html}}$ [accessed 2021-03-22]

8. Mounk Y. Cancel College: Reopening universities will accomplish little and endanger many. 2020 Aug 08. URL: https:/ /www.theatlantic.com/ideas/archive/2020/08/cancel-college/615064/ [accessed 2021-03-22]

9. Panovska-Griffiths J, Kerr CC, Stuart RM, Mistry D, Klein DJ, Viner RM, et al. Determining the optimal strategy for reopening schools, the impact of test and trace interventions, and the risk of occurrence of a second COVID-19 epidemic wave in the UK: a modelling study. The Lancet Child \& Adolescent Health 2020 Nov;4(11):817-827. [doi: $10.1016 / \mathrm{s} 2352-4642(20) 30250-9]$

10. Vermund S, Pitzer V. Asymptomatic transmission and the infection fatality risk for COVID-19: Implications for school reopening. Clin Infect Dis 2020 Jun 25:2020 [FREE Full text] [doi: 10.1093/cid/ciaa855] [Medline: $\underline{32584967]}$

11. Di Domenico L, Pullano G, Sabbatini CE, Boëlle P, Colizza V. Impact of lockdown on COVID-19 epidemic in Île-de-France and possible exit strategies. BMC Med 2020 Jul 30;18(1):1-13. [doi: 10.1186/s12916-020-01698-4]

12. Byrne R, Cassell G, Downs M. Planning For On-Campus K-12 Education During Covid-19. Healthcare Coalition. 2020. URL: https://www.mitre.org/sites/default/files/publications/planning-on-campus-K12-education-during-covid19-august2020. pdf [accessed 2021-03-22]

13. Bond E, Dibner K, Schweingruber H. Reopening K-12 Schools During the COVID-19 Pandemic: Prioritizing Health, Equity, and Communities. In: Critical Findings on COVID-19: Select Publications from the National Academies of Sciences, Engineering, and Medicine. Washington DC: The National Academies Press; 2021.

14. Wood G. There's no simple way to reopen universities. The Atlantic. 2020. URL: https://www.theatlantic.com/ideas/archive/ 2020/04/colleges-are-weighing-costs-reopening-fall/610759/ [accessed 2021-03-22]

15. Duffin E. College enrollment in the United States from 1965 to 2018 and projections up to 2029 for public and private colleges. Statista. 2020. URL: https://www.statista.com/statistics/183995/ us-college-enrollment-and-projections-in-public-and-private-institutions [accessed 2021-03-22]

16. Barton D. Impacts of the COVID-19 pandemic on field instruction and remote teaching alternatives: Results from a survey of instructors. Ecol Evol 2020 Aug 07;10(22):12499-12507 [FREE Full text] [doi: 10.1002/ece3.6628] [Medline: 32837715 ]

17. North R, Vitto C, Hickam G, Santen S. Remote Learning in the Time of COVID-19. AEM Educ Train 2020 Jul;4(3):280-283 [FREE Full text] [doi: 10.1002/aet2.10483] [Medline: 32695955]

18. Gross L. Learning Together During the COVID-19 Experience. J Am Water Works Assoc 2020 Aug;112(8):81-83 [FREE Full text] [doi: 10.1002/awwa.1560] [Medline: $\underline{32843770]}$

19. Here's Our List of Colleges' Reopening Models. The Chronicle of Higher Education. 2020. URL: https:/tinyurl.com/ 9t4pf8k9 [accessed 2021-03-22]

20. Largest University System in US, Cal State, Moves Fall Classes Online. Learning English. 2020 May 13. URL: https:/ /tinyurl.com/nhdkwmfk [accessed 2021-03-22] 
21. Weeden K, Cornwell B. The small-world network of college classes: implications for epidemic spread on a university campus. Sociological Science 2020;7(9):222-241. [doi: 10.15195/v7.a9]

22. Quintana C. COVID-19 will hit colleges when students arrive for fall semester. So why open at all? Money is a factor. USA Today. 2020 Aug 17. URL: https://tinyurl.com/jxasvj3v [accessed 2021-03-22]

23. Cashore J, Duan N, Janmohamed A, Wan J, Zhang Y, Henderson S, et al. COVID-19 Mathematical Modeling for Cornell's Fall Semester. Cornell University. 2020 Jun 15. URL: https://tinyurl.com/3t98hsdj [accessed 2021-03-22]

24. Madhusoodanan J. 'Ethically troubling.' University reopening plans put professors, students on edge. Science. 2020 Jul 20. URL: https://www.sciencemag.org/careers/2020/07/ ethically-troubling-university-reopening-plans-put-professors-students-edge [accessed 2021-03-22]

25. Bansal S, Carlson C, Kraemer J. There is no safe way to reopen colleges this fall. The Washington Post. 2020 Jun 30. URL: https://www.washingtonpost.com/outlook/2020/06/30/there-is-no-safe-way-reopen-colleges-this-fall/ [accessed 2021-03-22]

26. Whitford E. August wave of campus reopening reversals. Inside Higher Ed. 2020 Aug 12. URL: https://www. insidehighered.com/news/2020/08/12/hundreds-colleges-walk-back-fall-reopening-plans-and-opt-online-only-instruction [accessed 2021-03-22]

27. Hadden J. What the top 25 colleges and universities in the US have said about their plans to reopen in fall 2020 , from postponing the semester to offering more remote coursework. Business Insider. $2020 \mathrm{Jul} 28$. URL: https://www. businessinsider.com/how-major-us-colleges-plan-reopen-for-fall-2020-semester-2020-5 [accessed 2021-03-22]

28. Kroichick R. Stanford's plan for fall quarter: Most classes online, half the students on campus. San Francisco Chronicle. 2020 Jun 29. URL: https://www.sfchronicle.com/education/article/Stanford-s-plan-for-fall-quarter-Most-classes- 15375374. php [accessed 2021-03-22]

29. Aspegren E, Zwickel S. In person, online classes or a mix: colleges' fall 2020 coronavirus reopening plans, detailed. USA Today. 2020 Jun 22. URL: https://www.usatoday.com/story/news/education/2020/06/22/ coronavirus-reopening-college-fall-2020/3210719001/ [accessed 2021-03-22]

30. Brindley E, Murdock Z. UConn revokes on-campus housing for students captured on video partying in a packed dorm room without face masks. Hartford Courant. 2020 Aug 18. URL: https://www.courant.com/coronavirus/ hc-news-coronavirus-uconn-quarantine-positive-tests-20200818-kjvaf6xmvngp5jatyxsbdl5gwa-story.html [accessed 2021-03-22]

31. Chua E. BU should go fully online this fall. BU Today. 2020 Jul 09. URL: http://www.bu.edu/articles/2020/ why-bu-should-go-fully-online-this-fall/ [accessed 2021-03-22]

32. Northeastern is open. Northeastern University. URL: https://news.northeastern.edu/coronavirus/ [accessed 2021-03-22]

33. Hellewell J, Abbott S, Gimma A, Bosse NI, Jarvis CI, Russell TW, Centre for the Mathematical Modelling of Infectious Diseases COVID-19 Working Group, et al. Feasibility of controlling COVID-19 outbreaks by isolation of cases and contacts. Lancet Glob Health 2020 Apr;8(4):e488-e496 [FREE Full text] [doi: 10.1016/S2214-109X(20)30074-7] [Medline: 32119825]

34. Oran D, Topol E. Prevalence of Asymptomatic SARS-CoV-2 Infection: A Narrative Review. Ann Intern Med 2020 Sep 01;173(5):362-367 [FREE Full text] [doi: 10.7326/M20-3012] [Medline: 32491919]

35. Brüssow H. COVID-19: test, trace and isolate-new epidemiological data. Environ Microbiol 2020 Jul;22(7):2445-2456 [FREE Full text] [doi: 10.1111/1462-2920.15118] [Medline: 32510748]

36. Lauer S, Grantz K, Bi Q, Jones FK, Zheng Q, Meredith HR, et al. The Incubation Period of Coronavirus Disease 2019 (COVID-19) From Publicly Reported Confirmed Cases: Estimation and Application. Ann Intern Med 2020 May 05;172(9):577-582 [FREE Full text] [doi: 10.7326/M20-0504] [Medline: 32150748]

37. If you've been exposed to the coronavirus. Harvard Health Publishing. 2020. URL: https://www.health.harvard.edu/ diseases-and-conditions/if-youve-been-exposed-to-the-coronavirus [accessed 2021-03-22]

38. Albom M. Young people and bars are a recipe for coronavirus. The Daily Herald. 2020 Jun 29. URL: https://www. columbiadailyherald.com/story/opinion/2020/06/29/young-people-and-bars-are-recipe-for-coronavirus/41741699/ [accessed 2021-03-22]

39. Kealy C. Virginia Tech confirms five total positive COVID-19 cases ahead of first day of classes. ABC News. 2020 Aug 18. URL: https://wset.com/news/local/ virginia-tech-provides-update-to-community-covid-19-dashboard-to-be-released-this-week [accessed 2021-03-22]

40. Wong W. UNC-Chapel Hill goes to remote learning after 135 COVID-19 cases within week of starting classes. NBC News. 2020 Aug 18. URL: https://www.nbcnews.com/news/us-news/ unc-chapel-hill-converts-remote-learning-after-reporting-135-new-n1236977 [accessed 2021-03-22]

41. Bono G, Reil K, Hescox J. Stress and wellbeing in urban college students in the US during the COVID-19 pandemic: Can grit and gratitude help? International Journal of Wellbeing 2020;10(3):1 [FREE Full text]

42. Gurukkal R. Will COVID 19 Turn Higher Education into Another Mode? Higher Education for the Future 2020 Jun 07;7(2):89-96. [doi: 10.1177/2347631120931606]

43. Thorbecke C. Why coronavirus-battered universities may not be able to use their endowments. ABC News. 2020 Apr 25. URL: https://abcnews.go.com/US/coronavirus-battered-universities-endowments/story?id=70305591 [accessed 2021-03-22] 
44. Gardner LG. Colleges face a no-win dilemma: to cut or not to cut tuition? The Chronicle of Higher Education. 2020 Jul 15. URL: https://www.chronicle.com/article/colleges-face-a-no-win-dilemma-to-cut-or-not-to-cut-tuition [accessed 2021-03-22]

45. Mirza C. How COVID-19 can reinvent higher education. QS Wow News. 2020 May 05. URL: https://qswownews.com/ how-covid-19-can-reinvent-higher-education/ [accessed 2021-03-22]

46. Sullivan R. College towns and COVID-19: the impact on New England.: Federal Reserve Bank of Boston; 2020. URL: https://www.bostonfed.org/-/media/Documents/Workingpapers/PDF/2020/neppcrb2003.pdf [accessed 2021-03-29]

47. Viner R, Bonell C, Drake L, Jourdan D, Davies N, Baltag V, et al. Reopening schools during the COVID-19 pandemic: governments must balance the uncertainty and risks of reopening schools against the clear harms associated with prolonged closure. Arch Dis Child 2021 Feb;106(2):111-113 [FREE Full text] [doi: 10.1136/archdischild-2020-319963] [Medline: 32747375]

48. DePietro A. Here's A Look At The Impact Of Coronavirus (COVID-19) On Colleges And Universities In The U.S. Forbes. 2020 Apr 30. URL: https://www.forbes.com/sites/andrewdepietro/2020/04/30/ impact-coronavirus-covid-19-colleges-universities/\#531cfb1461a6 [accessed 2021-03-22]

49. Lederman D. Low-income students top presidents' COVID-19 worry list. Inside Higher Ed. 2020 Apr 27. URL: https:/ /tinyurl.com/exaf8k6p [accessed 2021-03-22]

50. Lederman D. COVID-19's forceful financial hit: a survey of business officers. Inside Higher Ed. 2020 Jul 10. URL: https:/ /www.insidehighered.com/news/survey/covid-19s-forceful-financial-hit-survey-business-officers [accessed 2021-03-22]

51. Borter G, Layne N. North Carolina university is latest U.S. school to roll back campus reopening. Reuters. 2020 Aug 17. URL: https://www.reuters.com/article/us-health-coronavirus-usa-idUSKCN25D28R [accessed 2021-03-22]

52. Tracking COVID-19 at Notre Dame. The Observer. 2020 Aug 15. URL: https://ndsmcobserver.com/2020/08/ tracking-covid-19-at-notre-dame/ [accessed 2021-03-22]

53. Mansell W, Lynn S. Significant number of Navy midshipmen test positive on return to school. ABC News. 2020 Aug 15. URL: https://abcnews.go.com/US/coronavirus-updates-florida-approves-return-high-school-sports/story?id=72390166 [accessed 2021-03-22]

54. Treisman R. Michigan State And Notre Dame suspend in-person learning over COVID-19 concerns. NPR. 2020 Aug 18. URL: https://www.npr.org/sections/coronavirus-live-updates/2020/08/18/903707406/ michigan-state-and-notre-dame-suspend-in-person-learning-over-covid-19-concerns [accessed 2021-03-22]

55. Jones A. 19 states see Covid-19 outbreaks on college campuses. CNN. 2020. URL: https://www.cnn.com/videos/health/ 2020/08/21/coronavirus-daily-wrap-colleges-vaccine-jones-dnt-lead-vpx.cnn [accessed 2021-03-22]

56. Lingi M. High Schools Scramble to Contain Coronavirus Outbreaks. CBS. 2020. URL: https://tinyurl.com/y6w46572 [accessed 2021-03-22]

57. Parshley L. 'This is exactly what we've been warning about': Why some school reopenings have backfired. Vox. 2020. URL: https://www.vox.com/2020/8/17/21371822/covid-19-prevention-kids-georgia-mississippi-texas [accessed 2021-03-22]

58. Aaro D. At least 31 percent of children tested in Florida are positive for COVID-19: report. FOX News. 2020 Jul 15. URL: https://www.foxnews.com/health/over-31-percent-florida-children-tested-florida-positive-covid-19-report [accessed 2021-03-22]

59. Social gatherings produce increase in student COVID-19 cases. Public Affairs, UC Berkeley. 2020 Jul 08. URL: https:/ Inews.berkeley.edu/2020/07/08/social-gatherings-produce-increase-in-student-covid-19-cases/ [accessed 2021-03-22]

60. Zachariah P, Johnson C, Halabi K, Ahn D, Sen AI, Fischer A, Columbia Pediatric COVID-19 Management Group. Epidemiology, Clinical Features, and Disease Severity in Patients With Coronavirus Disease 2019 (COVID-19) in a Children's Hospital in New York City, New York. JAMA Pediatr 2020 Oct 01;174(10):e202430 [FREE Full text] [doi: 10.1001/jamapediatrics.2020.2430] [Medline: 32492092]

61. Liu Y, Gu Z, Xia S, Shi B, Zhou XN, Shi Y, et al. What are the underlying transmission patterns of COVID-19 outbreak? An age-specific social contact characterization. EClinicalMedicine 2020 May;22:100354 [FREE Full text] [doi: 10.1016/j.eclinm.2020.100354] [Medline: 32313879]

62. What should I know about coronavirus and children? Boston Children's Hospital. URL: http://www.childrenshospital.org/ conditions-and-treatments/conditions/c/coronavirus [accessed 2021-03-22]

63. Prosper O, Saucedo O, Thompson D, Torres-Garcia G, Wang X, Castillo-Chavez C. Modeling control strategies for concurrent epidemics of seasonal and pandemic H1N1 influenza. Math Biosci Eng 2011 Jan;8(1):141-170 [ㅍEE Full text] [doi: 10.3934/mbe.2011.8.141] [Medline: 21361405]

64. Choi Y, Jit M, Flasche S, Gay N, Miller E. Mathematical modelling long-term effects of replacing Prevnar7 with Prevnar13 on invasive pneumococcal diseases in England and Wales. PLoS One 2012;7(7):e39927 [FREE Full text] [doi: 10.1371/journal.pone.0039927] [Medline: 22808073]

65. Mishra S, Pickles M, Blanchard J, Moses S, Shubber Z, Boily MC. Validation of the modes of transmission model as a tool to prioritize HIV prevention targets: a comparative modelling analysis. PLoS One 2014;9(7):e101690 [REEE Full text] [doi: 10.1371/journal.pone.0101690] [Medline: 25014543] 
66. Yang Z, Zeng Z, Wang K, Wong SS, Liang W, Zanin M, et al. Modified SEIR and AI prediction of the epidemics trend of COVID-19 in China under public health interventions. J Thorac Dis 2020 Mar;12(3):165-174 [FREE Full text] [doi: 10.21037/jtd.2020.02.64] [Medline: 32274081]

67. Kermack WO, McKendrick AG. A contribution to the mathematical theory of epidemics. Proceedings of The Royal Society Of London 1927;115(772):700-721. [doi: 10.1098/rspa.1927.0118]

68. Hoppenstaedt F. Mathematical theories of populations: demographics, genetics and epidemics. Philadelphia, PA, USA: SIAM; 1975.

69. Ramli M, Chaira Zulfa S, Ayuningtia Chaniago N, Halfiani V. Mathematical analysis on SEIR-type model of the Tuberculosis disease spread with vaccination and treatment elements. J Phys Conf Ser 2019 Jul 23;1235:012120. [doi: 10.1088/1742-6596/1235/1/012120]

70. Side S, Mulbar U, Sidjara S, Sanusi W. A SEIR model for transmission of tuberculosis. In: AIP Conference Proceedings. 2017 Presented at: The 4th International Conference on Mathematical Sciences; November 15-17, 2016; Putrajaya, Malaysia p. 020004 URL: https://www.researchgate.net/publication/316550412_A_SEIR_model_for_transmission_of_tuberculosis [doi: $10.1063 / 1.4980867]$

71. Dantas E, Tosin M, Cunha Jr A. Calibration of a SEIR-SEI epidemic model to describe the Zika virus outbreak in Brazil. Applied Mathematics and Computation 2018 Dec;338:249-259. [doi: 10.1016/j.amc.2018.06.024]

72. McGee A. Zika virus transmission using two overlapping SEIR models.: ProQuest Dissertations Publishing; 2018. URL: https://search.proquest.com/openview/58a60d15179a056fc99e1e1958657713/1?pq-origsite $=$ gscholar \&cbl=18750\&diss $=\mathrm{y}$ [accessed 2021-03-25]

73. Lekone P, Finkenstädt BF. Statistical inference in a stochastic epidemic SEIR model with control intervention: Ebola as a case study. Biometrics 2006 Dec;62(4):1170-1177. [doi: 10.1111/j.1541-0420.2006.00609.x] [Medline: 17156292]

74. Wakeland W, Nielsen A, Schmidt T. System dynamics modeling of medical use, nonmedical use and diversion of prescription opioid analgesics. In: 30th International System Dynamics Conference. 2012 Presented at: 30th International System Dynamics Conference; 2012; St Gallen, Switzerland URL: https://pdxscholar.library.pdx.edu/cgi/viewcontent. cgi?filename $=0 \&$ article $=1064 \&$ context $=$ sysc fac $\&$ type $=$ additional

75. Wakeland W, Nielsen A, Schmidt T, McCarty D, Webster LR, Fitzgerald J, et al. Modeling the impact of simulated educational interventions on the use and abuse of pharmaceutical opioids in the United States: a report on initial efforts. Health Educ Behav 2013 Oct;40(1 Suppl):74S-86S [FREE Full text] [doi: 10.1177/1090198113492767] [Medline: 24084403]

76. White E, Comiskey C. Heroin epidemics, treatment and ODE modelling. Math Biosci 2007 Jul;208(1):312-324. [doi: 10.1016/j.mbs.2006.10.008] [Medline: 17174346]

77. Kang H, Wang Y, Tong Z, Liu X. Retest positive for SARS-CoV-2 RNA of "recovered" patients with COVID-19: Persistence, sampling issues, or re-infection? J Med Virol 2020 Nov;92(11):2263-2265 [FREE Full text] [doi: 10.1002/jmv.26114] [Medline: 32492212$]$

78. Naylor T, Finger J. Verification of computer simulation models. Management Science 1967;14(2):92-101.

79. Law A. Simulation Modeling and Analysis. 2nd ed. New York: McGraw-Hill; 1991.

80. McHale M, Friedman J, Karian J. Introduction to Validation Methodology. In: Standard for Verification and Validation in Computational Fluid Dynamics and Heat Transfer. New York: The American Society of Mechanical Engineers; 2009:1-5.

81. Sargent R. A New Statistical Procedure for Validation of Simulation and Stochastic Models. Syracuse, New York: Syracuse University; 2010.

82. Model validation principles applied to risk and capital models in the insurance industry. 2012. URL: http://www. crocouncil.org/images/CRO Council - Model Validation Principles.pdf [accessed 2021-03-25]

83. Edlund S, Kaufman J, Lessler J, Douglas J, Bromberg M, Kaufman Z, et al. Comparing three basic models for seasonal influenza. Epidemics 2011 Sep;3(3-4):135-142 [FREE Full text] [doi: 10.1016/j.epidem.2011.04.002] [Medline: 22094336]

84. González-Parra G, Arenas A, Aranda D, Segovia L. Modeling the epidemic waves of AH1N1/09 influenza around the world. Spat Spatiotemporal Epidemiol 2011 Dec;2(4):219-226. [doi: 10.1016/j.sste.2011.05.002] [Medline: 22748221]

85. Venkatramanan S, Lewis B, Chen J, Higdon D, Vullikanti A, Marathe M. Using data-driven agent-based models for forecasting emerging infectious diseases. Epidemics 2018 Mar;22:43-49 [FREE Full text] [doi: 10.1016/j.epidem.2017.02.010] [Medline: 28256420]

86. Ameri K, Cooper KD. A Network-Based Compartmental Model For The Spread Of Whooping Cough In Nebraska. AMIA Jt Summits Transl Sci Proc 2019;2019:388-397 [FREE Full text] [Medline: 31258992]

87. Mahdizadeh GN, Mesgari M, Hooshangi N. Developing an agent-based model for simulating the dynamic spread of Plasmodium vivax malaria: A case study of Sarbaz, Iran. Ecological Informatics 2019;54:101006. [doi: 10.1016/j.ecoinf.2019.101006]

88. Montalan J, Estuar M, Teknomo K, Gardon R. Measles metapopulation modeling using ideal flow of transportation networks. 2019 Presented at: 2nd International Conference on Software Engineering and Information Management; 2019; Bali, Indonesia URL: https://dl.acm.org/doi/abs/10.1145/3305160.3305210

89. Naserpor A, Niakan Kalhori SR, Ghazisaeedi M, Azizi R, Hosseini Ravandi M, Sharafie S. Modification of the Conventional Influenza Epidemic Models Using Environmental Parameters in Iran. Healthc Inform Res 2019 Jan;25(1):27-32 [FREE Full text] [doi: 10.4258/hir.2019.25.1.27] [Medline: $\underline{\text { 30788178] }}$ 
90. Systrom K, Vladeck T, Krieger M. Rt: Effective Reproductive Number. URL: https://rt.live/ [accessed 2021-03-22]

91. Gaskins N. CU Boulder: Increase in COVID-19 positive tests expected. Yahoo! News. 2020. URL: https://news.yahoo.com/ cu-boulder-increase-covid-19-180135153.html [accessed 2021-03-22]

92. Maccabe T. One percent of Purdue students test positive for COVID-19. WRTV Indianapolis. 2020 Aug 12. URL: https:/ /www.wrtv.com/news/coronavirus/covid-19-education/one-percent-of-purdue-students-test-positive-for-covid-19 [accessed 2021-03-22]

93. Mansell W, Lynn S. Significant number of Navy midshipmen test positive on return to school. Yahoo! News. 2020. URL: https://www.yahoo.com/gma/coronavirus-updates-florida-approves-return-103509067.html [accessed 2021-03-22]

94. Rahmandad H, Lim T, Sterman J. Behavioral Dynamics of COVID-19: Estimating Under-Reporting, Multiple Waves, and Adherence Fatigue Across 92 Nations. SSRN Journal 2020:1-73. [doi: 10.2139/ssrn.3635047]

95. COVID-19 coronavirus incubation. Worldometer. 2020. URL: https://www.worldometers.info/coronavirus/ coronavirus-incubation-period/ [accessed 2021-03-22]

96. Interim Clinical Guidance for Management of Patients with Confirmed Coronavirus Disease (COVID-19). Centers for Disease Control and Prevention. 2020. URL: https://www.cdc.gov/coronavirus/2019-ncov/hcp/ clinical-guidance-management-patients.html [accessed 2021-03-22]

97. Maragakis L. Coronavirus diagnosis: what should I expect? Johns Hopkins Medicine. 2020. URL: https://www. hopkinsmedicine.org/health/conditions-and-diseases/coronavirus/diagnosed-with-covid-19-what-to-expect [accessed 2020-07-07]

98. Sakurai A, Sasaki T, Kato S, Hayashi M, Tsuzuki S, Ishihara T, et al. Natural History of Asymptomatic SARS-CoV-2 Infection. N Engl J Med 2020 Aug 27;383(9):885-886 [FREE Full text] [doi: 10.1056/NEJMc2013020] [Medline: 32530584]

99. Report of the WHO-China Joint Mission on Coronavirus Disease 2019 (COVID-19). World Health Organization. 2020. URL: https://www.who.int/publications/i/item/report-of-the-who-china-joint-mission-on-coronavirus-disease-2019-(covid-19) [accessed 2021-03-22]

100. Mortality Analyses. Johns Hopkins Medicine Coronavirus Resource Center. 2020. URL: https://coronavirus.jhu.edu/data/ mortality [accessed 2021-03-22]

101. Perez-Saez F, Lauer S, Kaiser L, Regard S, Delaporte E, Guessous I, Serocov-POP Study Group. Serology-informed estimates of SARS-CoV-2 infection fatality risk in Geneva, Switzerland. Lancet Infect Dis 2020 Jul 14:e69-e70 [FREE Full text] [doi: 10.1016/S1473-3099(20)30584-3] [Medline: 32679085]

102. Wiersinga WR, Rhodes A, Cheng AC, Peacock SJ, Prescott HC. Pathophysiology, Transmission, Diagnosis, and Treatment of Coronavirus Disease 2019 (COVID-19): A Review. JAMA 2020 Aug 25;324(8):782-793. [doi: 10.1001/jama.2020.12839] [Medline: 32648899]

103. Coronavirus (Covid-19) data in the United States. The New York Times. URL: https://github.com/nytimes/covid-19-data [accessed 2021-03-22]

104. University of Washington. 2020. URL: https://www.washington.edu/coronavirus/ ?utm source=uwhp\&utm medium=tiles\&utm campaign=covid-safe-start [accessed 2021-03-22]

105. Chronology of Purdue's response to COVID-19. Purdue University. 2020. URL: https://protect.purdue.edu/timeline/ [accessed 2021-03-22]

106. Richards M, Janes J. Resiliency planning for autumn quarter. University of Washington. 2020. URL: https://www. washington.edu/coronavirus/2020/05/28/resiliency-planning-for-autumn-quarter/ [accessed 2021-03-22]

107. Return to Rice. Rice University. 2020. URL: https://coronavirus.rice.edu/ [accessed 2021-03-22]

108. COVID-19 health alerts. Stanford University. 2020. URL: https://healthalerts.stanford.edu/covid-19/ [accessed 2021-03-22]

109. Safe and Healthy Buckeyes. Ohio State University. 2020. URL: https://safeandhealthy.osu.edu/ [accessed 2021-03-22]

110. Harter K, Raudins S. President Drake says on-campus transition could begin in coming weeks. The Lantern. 2020. URL: https://www.thelantern.com/2020/04/president-drake-says-on-campus-transition-could-begin-in-coming-weeks/ [accessed 2021-03-22]

111. Aoun JE. University Messages: Our Path Forward. News@ Northeastern. 2020. URL: https://news.northeastern.edu/ coronavirus/university-messages/our-path-forward/ [accessed 2021-03-22]

112. Latest information about coronavirus 2019 (COVID-19). California State University Bakersfield. 2020. URL: https://www. csub.edu/covid-19 [accessed 2021-03-22]

113. Smith A, Burke M, Gordon L. Quick Guide: California colleges and universities respond to the coronavirus. EdSource. 2020. URL: https://edsource.org/2020/california-colleges-and-universities-respond-to-the-coronavirus-a-quick-guide/626396 [accessed 2021-03-22]

114. Reopening. Eastern Connecticut State University. 2020. URL: https://www.easternct.edu/reopening/index.html [accessed 2021-03-22]

115. Hladky G. State college and university campuses to reopen for start of fall semester. The CT Mirror. 2020. URL: https:/ /ctmirror.org/2020/05/29/state-college-and-university-campuses-to-reopen-for-start-of-fall-semester/ [accessed 2021-03-22]

116. Box G, Draper N. Empirical Model-Building and Response Surfaces. New York: Wiley; 1987. 
117. Ivory D, Geneloff R, Mervosh S. Young people have less Covid-19 risk, but in college towns, deaths rose fast. The New York Times. 2020 Dec 12. URL: https://www.nytimes.com/2020/12/12/us/covid-colleges-nursing-homes.html [accessed 2021-03-22]

118. Hurd H, Kaneene J. The application of simulation models and systems analysis in epidemiology: a review. Preventive Veterinary Medicine 1993;15:81-99. [doi: 10.1016/0167-5877(93)90105-3]

\section{Abbreviations}

ODE: ordinary differential equation

Edited by T Sanchez; submitted 13.09.20; peer-reviewed by T Das, A Visser; comments to author 16.11.20; revised version received 30.12.20; accepted 03.03.21; published 07.04.21

Please cite as:

Benneyan J, Gehrke C, Ilies I, Nehls N

Community and Campus COVID-19 Risk Uncertainty Under University Reopening Scenarios: Model-Based Analysis JMIR Public Health Surveill 2021;7(4):e24292

URL: https://publichealth.jmir.org/2021/4/e24292

doi: $10.2196 / 24292$

PMID: 33667173

CJames Benneyan, Christopher Gehrke, Iulian Ilies, Nicole Nehls. Originally published in JMIR Public Health and Surveillance (http://publichealth.jmir.org), 07.04.2021. This is an open-access article distributed under the terms of the Creative Commons Attribution License (https://creativecommons.org/licenses/by/4.0/), which permits unrestricted use, distribution, and reproduction in any medium, provided the original work, first published in JMIR Public Health and Surveillance, is properly cited. The complete bibliographic information, a link to the original publication on http://publichealth.jmir.org, as well as this copyright and license information must be included. 